Thorax, 1978, $, 33,547-554$

\title{
Longitudinal respiratory studies in older people
}

\author{
J S MILNE
}

From the Geriatric Research Unit, Royal Victoria Hospital, Edinburgh, UK

Milne, J S (1978). Thorax, 33, 547-554. Longitudinal respiratory studies in older people. A random sample of older people in Edinburgh (215 men, 272 women aged 62-90 years) was examined with the MRC questionnaire on respiratory symptoms. The FEV $\mathrm{F}_{1}$ and FVC were recorded. Spirograms were repeated after one and five years and the questions after five years, the sample by then having been reduced to 133 men and 148 women.

After five years $7 \%$ of the surviving men and women had developed persistent cough and phlegm. This syndrome had disappeared in $12 \%$ of men and $2 \%$ of women. Dyspnoea had increased beyond grade 2 in $13 \%$ of men and $7 \%$ of women and had lessened only in $6 \%$ of women.

One-quarter of male and one-seventh of female cigarette smokers had given up smoking, mostly in the first year. Nearly all who stopped were symptomless before and after. In those men who stopped smoking before the study began symptom prevalence was similar to that in those who continued smoking.

Mean values of $\mathrm{FEV}_{1}$ and $\mathrm{FVC}$ declined as age increased, the decline being greater in FVC with resulting rise in $\mathrm{FEV}_{1} \%$. Five-year differences in $\mathrm{FEV}_{1}$ and $\mathrm{FVC}$ were symmetrically distributed with mean differences increasing with age. Mean differences in FEV were $_{1}$ 280-350 $\mathrm{ml}$ in men and 150-230 $\mathrm{ml}$ in women. Prediction equations from the first examinations remained usable for clinical work. Mean values of FEV 1 and FVC at the first examination were smaller in those who died compared with survivors, whether symptoms were present or not. The prevalence of symptoms was greater in those who died.

Several publications report data from population studies of respiratory function (Needham et al, 1954; Kory et al, 1961; Berglund et al, 1963; Ferris et al, 1965; Morris et al, 1973), but information in these about the elderly tends to be derived from a few subjects in series covering large age ranges. A few papers (Milne and Williamson, 1972(b); Schmidt et al, 1973) report studies made exclusively on the elderly. The present paper describes the repetition after one and five years of respiratory function tests in the subjects from one of these studies of the elderly. Details are also given about respiratory symptoms and cigarette smoking at follow-up.

\section{Subjects}

The people studied in the first examination were 215 men and 272 women aged 62-90 years who in 1968 formed a simple random sample of the population of 27000 people in that age range living in ten city wards in north Edinburgh. The method of sampling with a comparison of respondents and non-respondents has been described elsewhere (Milne et al, 1971). After the first examinations in 1968 and 1969 further examinations were made after one $(1969 / 70)$ and five $(1973 / 4)$ years. At the five-year examination it was possible to reexamine 113 men and 148 women. Information from these patients only has been used in analysing longitudinal data. During the five years 78 men and 60 women had died which left 24 men and 64 women surviving who for various reasons were not re-examined. Follow-up of the sample has been described in detail elsewhere (Milne and Chopin, 1975).

\section{Methods}

Subjects were questioned with the MRC questionnaire on respiratory symptoms (1965) at the first examination (1968/9). The questions were asked 
again at the five-year review (1973/4). At the first examination smoking habits were studied in detail (Milne and Williamson, 1972(a)), but at the oneyear and five-year reviews subjects were asked only whether they still smoked cigarettes and if so, how many a day. The reproducibility of the questionnaires was tested before the survey began (Milne et al, 1970).

The respiratory function tests were the forced expiratory volume in one second $\left(\mathrm{FEV}_{1}\right)$ and the forced vital capacity (FVC) performed on a Vitalograph spirometer. This instrument was reported suitable by Drew and Hughes (1969) for measuring FEV 1 and FVC in population studies of normal subjects and of those with obstructive airways disease. Tests were performed with subjects sitting, and the best of three readings was used in the analysis. Height was measured with a Harpenden stadiometer. Reproducibility of the tests and calibration of the Vitalograph were satisfactory and have been reported elsewhere (Milne and Williamson, 1972(b)). The $\mathrm{FEV}_{1} \%$ was calculated as $\left(\mathrm{FEV}_{1} \times 100\right) / \mathrm{FVC}$.

\section{Results}

SYMPTOM PREVALENCE AND INCIDENCE

Replies to questions from the MRC questionnaire on respiratory symptoms (1965) have been analysed in table 1 in respect of persistent cough and phlegm, chest infections, and dyspnoea at the original and at the five-year examination.

Cigarette-smokers were sought by the question: "Do you smoke cigarettes now?", which was also asked on each occasion. The first two columns enumerate subjects in whom the symptom was present or absent on both occasions. The thir column shows the proportion of subjects whose symptoms developed during the five-year period while the fourth column gives the proportion whose symptoms disappeared during the same period.

Some points from the table need comment $\overrightarrow{\vec{\omega}}$ Similar proportions of men $(7 \cdot 1 \%)$ and of wome

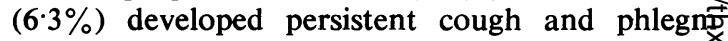
during the five years. In the same period the syn drome disappeared in $11.6 \%$ of men and $2.1 \%$ of women. Only three men and two women becamer subject to repeated chest infections during the five years, while in two men and one woman this symptom disappeared.

Dyspnoea increased beyond grade 2 during the five years in $13 \%$ of men and $7 \cdot 3 \%$ of women. If a similar proportion of women $(6.5 \%)$ dyspnoe lessened, but this improvement was claimed by only one man.

One-quarter of the men and just over one.0 seventh of the women who admitted smoking cigarettes at the original examination gave us during the five years. Eleven of 14 men who stopped smoking during the five years gave uf after one year, the corresponding figures in wome 8 being three of four.

There were no significant age differences in the incidence figures, which were therefore reported separately only by sex.

Stopping smoking during the five years of the study showed little effect on symptoms since 13 of 14 men and all four women who stopped during the period did not have persistent cough an

Table 1 Respiratory symptoms and cigarette smoking, in a longitudinal study of older men and women, recorded at start of study and at five-year follow-up. (Percentages in parentheses)

\begin{tabular}{|c|c|c|c|c|c|}
\hline Symptom & $\begin{array}{l}\text { Absent } \\
\text { both times }\end{array}$ & $\begin{array}{l}\text { Present } \\
\text { both times }\end{array}$ & $\begin{array}{l}\text { Present } \\
\text { at } 5 \text {-year exam } \\
\text { only }\end{array}$ & $\begin{array}{l}\text { Present } \\
\text { at first exam } \\
\text { only }\end{array}$ & $\begin{array}{l}\text { No of } \\
\text { Subjects }\end{array}$ \\
\hline \multicolumn{6}{|l|}{ Men } \\
\hline Persistent cough and phlegm & $\begin{array}{l}72 \\
(64 \cdot 3)\end{array}$ & $\begin{array}{l}19 \\
(17 \cdot 0)\end{array}$ & $\left(\begin{array}{l}8 \\
7 \cdot 1\end{array}\right)$ & $\begin{array}{l}13 \\
(11 \cdot 6)\end{array}$ & 112 \\
\hline Persistent cough and phlegm plus chest infection & $\begin{array}{l}103 \\
(92 \cdot 0)\end{array}$ & $\left(\begin{array}{l}4 \\
(3 \cdot 6)\end{array}\right.$ & $\left(\begin{array}{l}3 \\
2 \cdot 7)\end{array}\right.$ & $\left(\begin{array}{l}2 \\
1 \cdot 8)\end{array}\right.$ & 112 \\
\hline Dyspnoea worse than grade 2 & $\begin{array}{l}79 \\
(79)\end{array}$ & $\begin{array}{l}7 \\
7\end{array}$ & $\begin{array}{c}13 \\
(13)\end{array}$ & ( 1$)$ & 100 \\
\hline Smokes cigarettes & $\begin{array}{l}55 \\
49 \cdot 1)\end{array}$ & $\begin{array}{l}42 \\
(37 \cdot 5)\end{array}$ & $(0.9)$ & $(12 \cdot 5)$ & 112 \\
\hline \multicolumn{6}{|l|}{ Women } \\
\hline Persistent cough and phlegm & $\begin{array}{l}123 \\
(86 \cdot 6)\end{array}$ & $\begin{array}{l}7 \\
(4 \cdot 9)\end{array}$ & $\begin{array}{l}9 \\
(6 \cdot 3)\end{array}$ & $\begin{array}{l}3 \\
(2 \cdot 1)\end{array}$ & 142 \\
\hline Persistent cough and phlegm plus chest infection & $\begin{array}{l}139 \\
(97.9)\end{array}$ & 0 & $\left(\begin{array}{l}2 \\
(1 \cdot 4)\end{array}\right.$ & $\left(\begin{array}{l}1 \\
0 \cdot 7)\end{array}\right.$ & 142 \\
\hline Dysponoea worse than grade 2 & $\begin{array}{c}99 \\
(79 \cdot 8)\end{array}$ & $\begin{array}{l}8 \\
(6 \cdot 5)\end{array}$ & $\begin{array}{l}9 \\
(7 \cdot 3\end{array}$ & $\begin{array}{l}8 \\
(6 \cdot 5)\end{array}$ & 124 \\
\hline Smokes cigarettes & $\begin{array}{l}113 \\
(79 \cdot 6)\end{array}$ & $\begin{array}{l}24 \\
(16 \cdot 9)\end{array}$ & $\left(\begin{array}{l}1 \\
0 \cdot 7)\end{array}\right.$ & $\begin{array}{l}4 \\
(2 \cdot 8)\end{array}$ & 142 \\
\hline
\end{tabular}


phlegm on either occasion of being questioned. The effect of stopping smoking earlier was not striking in older men. At the original examination 32 men smoked or had smoked cigarettes and admitted to persistent cough and phlegm. Ten of these men had stopped smoking cigarettes before the study began, but seven of these still had cough and phlegm at the five-year review. The mean time in years at the time of the original examination since stopping smoking was 11.6 (SD 10.0) with a range from one to 30 years. Of the remaining 22 men who continued to smoke, 12 had persistent cough and phlegm at the five-year review.

\section{MEAN VALUES OF RESPIRATORY FUNCTION TESTS AT} DIFFERENT STAGES OF THE STUDY

Mean values with $95 \%$ confidence limits of $\mathrm{FEV}_{1}$ and FVC are given for men and for women, each sex being divided into subjects aged less than 70 years and 70 years and over at entry to the study (fig 1). For each age and sex group in the figure there are three means with confidence limits representing (reading from left to right) measurements made at the original examination and after one and five years. Values for $\mathrm{FEV}_{1}$ are the lower and for FVC the upper groups in the diagram. The figure shows in each group a decline in the mean values as time passes.

The decline in mean values between those from the original examination and those obtained after

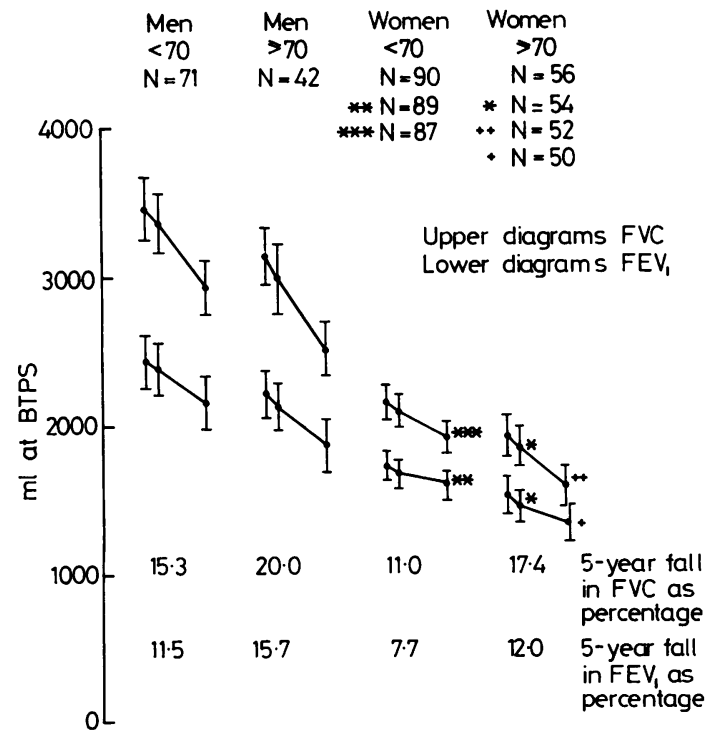

Fig 1 Mean values with $95 \%$ confidence limits of $F E V$, and $F V C$ in two age groups of older men and women. Results, from left to right in each group, are from a longitudinal study at zero, one, and five years. five years is steeper in all groups for FVC than for $F_{E V}$. The actual figures in which the five-year difference is expressed as a percentage of the original reading are given in the lower part of figure 1.

Mean values of $\mathrm{FEV}_{1} \%$ in the same age and sex groups are given in figure 2. All groups show an increase in the mean value during the five years, which corresponds to the greater reduction of FVC compared with $\mathrm{FEV}_{1}$ during the five years.

THE ASSOCIATION OF RESPIRATORY FUNCTION TESTS AND SYMPTOMS WITH SURVIVAL

After five years the original sample was divided into those who had survived and those who had died during the period. Mean values with standard errors of $\mathrm{FEV}_{1}$ and FVC are given in table 2 for those who died and for survivors in men and in women whose age at entry to the study was either less than 70 years or 70 years and more. In corresponding age and sex groups the values in those who died were significantly smaller, except in women aged under 70 . There were only 16 deaths in this group, which makes the confidence limits large. The 14 women and two men missing from the table were unable to perform the tests because of intellectual impairment.

Mean values of FEV 1 and FVC were examined in the above age and sex groups of those who died, and survivors with each group were divided into those with and without persistent cough and phlegm. In those who subsequently died mean values were less than in the survivors, whether symptoms were present or not. Lower mean values were present in any age/sex group with symptoms compared with the corresponding group without symptoms. Of 32 differences examined in this way, only two reached statistical significance.

Values of $\mathrm{FEV}_{1} \%$ were compared in members of the original sample who died or survived during five years. There being no age effect with this variable, division was by sex only. In men the mean value in those who died (63.3 SE 1.9 N 76) was significantly less than that in survivors (69.9 SE 1.1 N 137). The mean value in women who died (76.9 SE $2.2 \mathrm{~N} \mathrm{44)}$ was less than in surviving women (80.6 SE $0.8 \mathrm{~N}$ 199) but not significantly so.

Further division of those who died and survivors into those with and without persistent cough and phlegm showed mean values smaller in those who died than in survivors in corresponding groups, but none of the differences was significant.

The prevalence of respiratory symptoms and cigarette smoking, obtained at the original examination, is given for those who died and those who survived the next five years (table 3 ). In every 


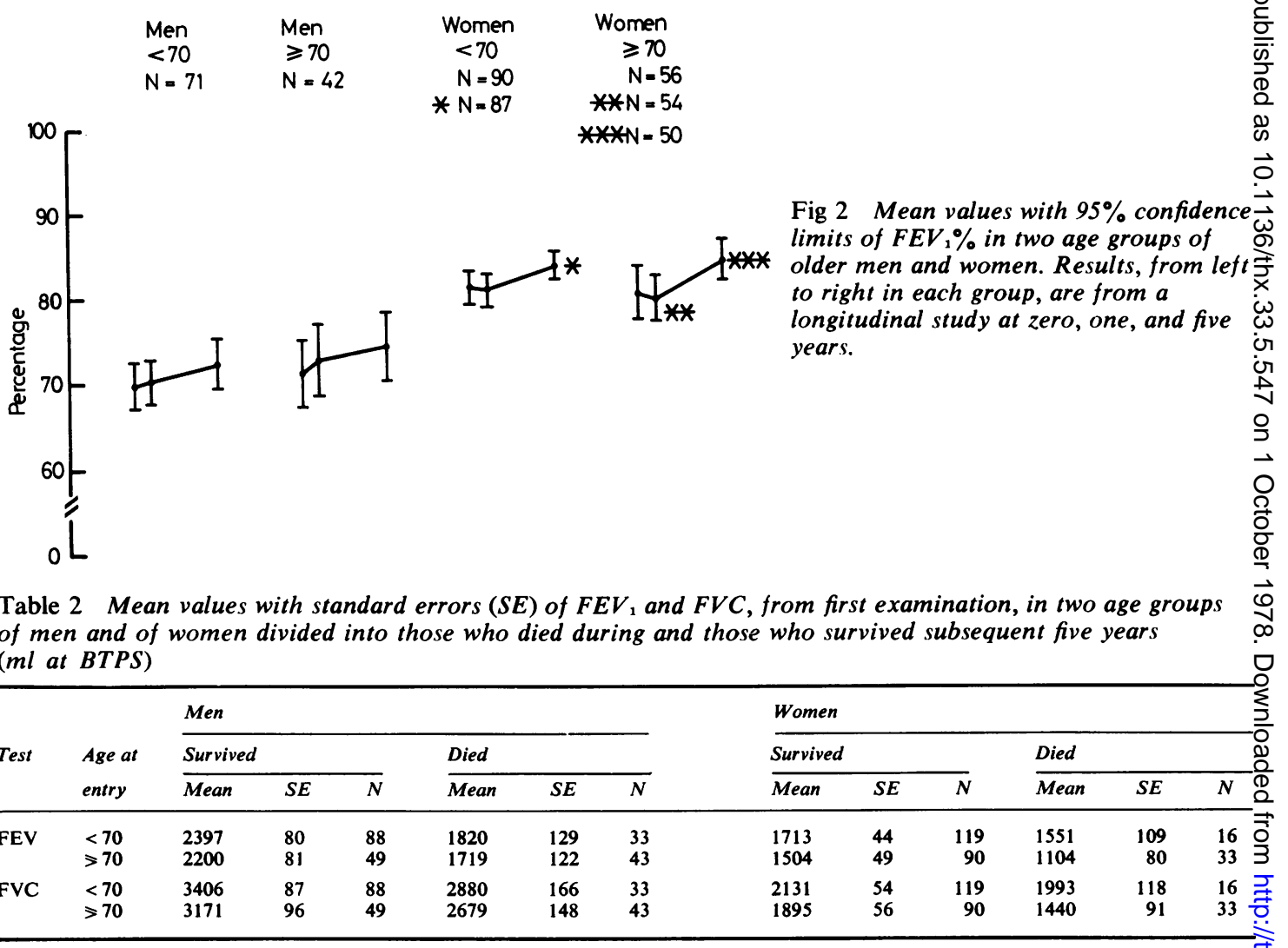

group, except cigarette smoking in women, the prevalence is greater in those who died than in those who survived. This difference reaches statistical significance in men in respect of persistent cough, persistent cough and phlegm with chest illness, and severe dyspnoea and in women in respect of severe dyspnoea only. Other points from the table are the higher prevalences of cough, phlegm, chest illness, and smoking in men and the higher prevalence of severe dyspnoea in women.

\section{DIFFERENCES IN FEV 1 , FVC, AND FEV $\%$ AFTER ONE} AND FIVE YEARS

The differences in $\mathrm{FEV}_{1}, \mathrm{FVC}$, and $\mathrm{FEV}_{1} \%$ after one and five years were calculated by subtracting, in each subject, the reading of each variable after one or five years from the reading at the first examination. Distributions of the one-and five-year differences, in men and in women, of each of the three variables are displayed in figures 3,4 , and 5 .

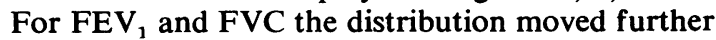
to the right after five years-that is a greater proportion of the sample showed a decrease in FEV, or FVC (figs 3 and 4). The distributions show that the percentage of the sample with a difference in FEV $_{1}$ which was greater than zero-that is, which reflected a decrease in $\mathrm{FEV}_{1}$ as time passed-rose from $66.4 \%$ of men and $63.5 \%$ of women after one year to $88.5 \%$ of men and $81.8 \%$ of women aftero five years. Corresponding percentages for FVC are $61.9 \%$ of men and $58.1 \%$ of women after one year and $92.0 \%$ of men and $86.5 \%$ of women afters five years.

The distributions of $\mathrm{FEV}_{1} \%$ moved to the left as time passed-that is, the value of $\mathrm{FEV}_{1} \%$ rose The percentages of the sample with a differences less than zero-that is, reflecting an increase in $\mathrm{FEV}_{1} \%$ as time passed-rose from $53.1 \%$ of menp and $44.1 \%$ of women after one year to $69.9 \%$ of men and $67.4 \%$ of women after five years (fig 5).

Attempts were made to relate symptoms to five? year differences in respiratory function tests byo comparing mean values of five-year differences in $\mathrm{FEV}_{1}$ and $\mathrm{FEV}_{1} \%$ in those who did not admit to cough and phlegm on either occasion with those who admitted these symptoms on at least one occasion. A similar comparison was made between those who smoked or had smoked cigarettes withe 
Table 3 Prevalence of respiratory symptoms and cigarette smoking at first examination in those who died and those who survived the next five years. (Percentages in parentheses)

\begin{tabular}{|c|c|c|c|c|c|}
\hline \multirow[b]{2}{*}{ Variable under comparison } & \multicolumn{2}{|l|}{ Dead } & \multicolumn{2}{|c|}{ Survivors } & \multirow[b]{2}{*}{$P$} \\
\hline & Absent & Present & Absent & Present & \\
\hline \multicolumn{6}{|l|}{ Men } \\
\hline Persistent cough & 40 & $\begin{array}{c}36 \\
(47 \cdot 4)\end{array}$ & 93 & $\begin{array}{l}44 \\
(32 \cdot 1)\end{array}$ & $<0.05$ \\
\hline Persistent phlegm & 38 & $\begin{array}{c}38 \\
(50)\end{array}$ & 85 & $\begin{array}{l}52 \\
(38)\end{array}$ & NS \\
\hline Persistent cough and phlegm & 46 & $\begin{array}{l}30 \\
(39 \cdot 5)\end{array}$ & 99 & $\begin{array}{l}38 \\
(27 \cdot 7)\end{array}$ & NS \\
\hline Persistent cough and phlegm with chest illness & 65 & $\begin{array}{l}11 \\
(14 \cdot 5)\end{array}$ & 130 & $\begin{array}{l}7 \\
(5 \cdot 1)\end{array}$ & $<0.05$ \\
\hline Dyspnoea worse than grade 2 & 52 & $\begin{array}{c}19 \\
(26.8)\end{array}$ & 118 & $\left(\begin{array}{l}12 \\
9 \cdot 2\end{array}\right)$ & $<0.01$ \\
\hline Smokes or smoked cigarettes & 14 & $\begin{array}{c}62 \\
(81 \cdot 6)\end{array}$ & 29 & $\begin{array}{l}108 \\
(78 \cdot 8)\end{array}$ & NS \\
\hline \multicolumn{6}{|l|}{ Women } \\
\hline Persistent cough & 47 & $\begin{array}{l}10 \\
(17 \cdot 5)\end{array}$ & 177 & $\begin{array}{l}34 \\
(16 \cdot 1)\end{array}$ & NS \\
\hline Persistent phlegm & 45 & $\begin{array}{l}12 \\
(21 \cdot 1)\end{array}$ & 181 & $\begin{array}{l}30 \\
(14 \cdot 2)\end{array}$ & NS \\
\hline Persistent cough and phlegm & 50 & $\begin{array}{c}7 \\
(12 \cdot 3)\end{array}$ & 193 & $\left(\begin{array}{c}18 \\
(8.5)\end{array}\right.$ & NS \\
\hline Persistent cough and phlegm with chest illness & 56 & $\begin{array}{l}1 \\
(1 \cdot 8)\end{array}$ & 210 & $\left(\begin{array}{l}1 \\
0.5\end{array}\right)$ & NS \\
\hline Dyspnoea worse than grade 2 & 28 & $\begin{array}{c}16 \\
(36 \cdot 4)\end{array}$ & 159 & $\begin{array}{l}32 \\
(16.8)\end{array}$ & $<0.01$ \\
\hline Smokes or smoked cigarettes & 47 & $\begin{array}{l}11 \\
\text { (19) }\end{array}$ & 152 & $\begin{array}{l}59 \\
(28)\end{array}$ & NS \\
\hline
\end{tabular}

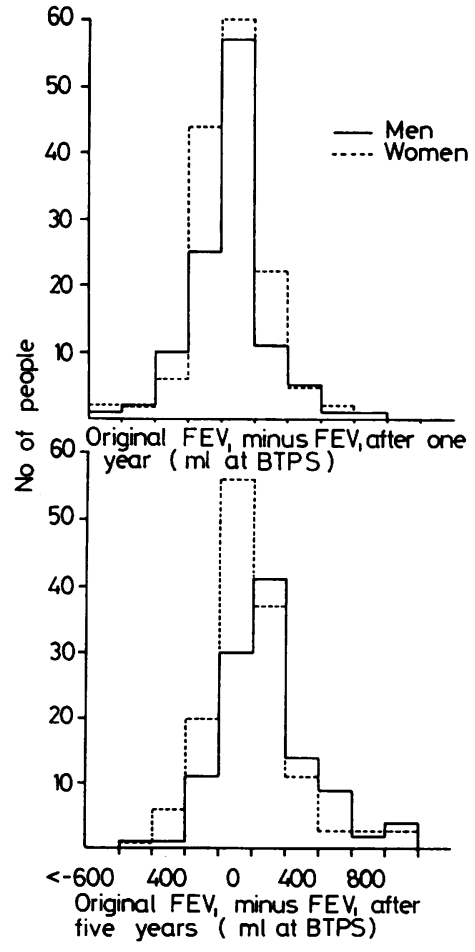

Fig 3 Distributions of one-year and five-year differences in FEV ${ }_{1}$ in older men and women.

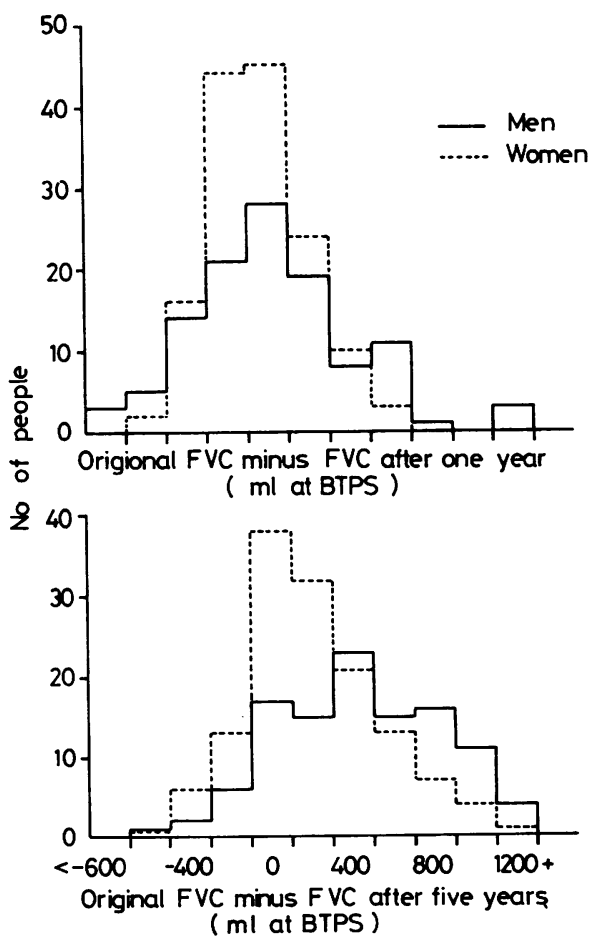

Fig 4 Distributions of one-year and five-year differences in FVC in older men and women. 

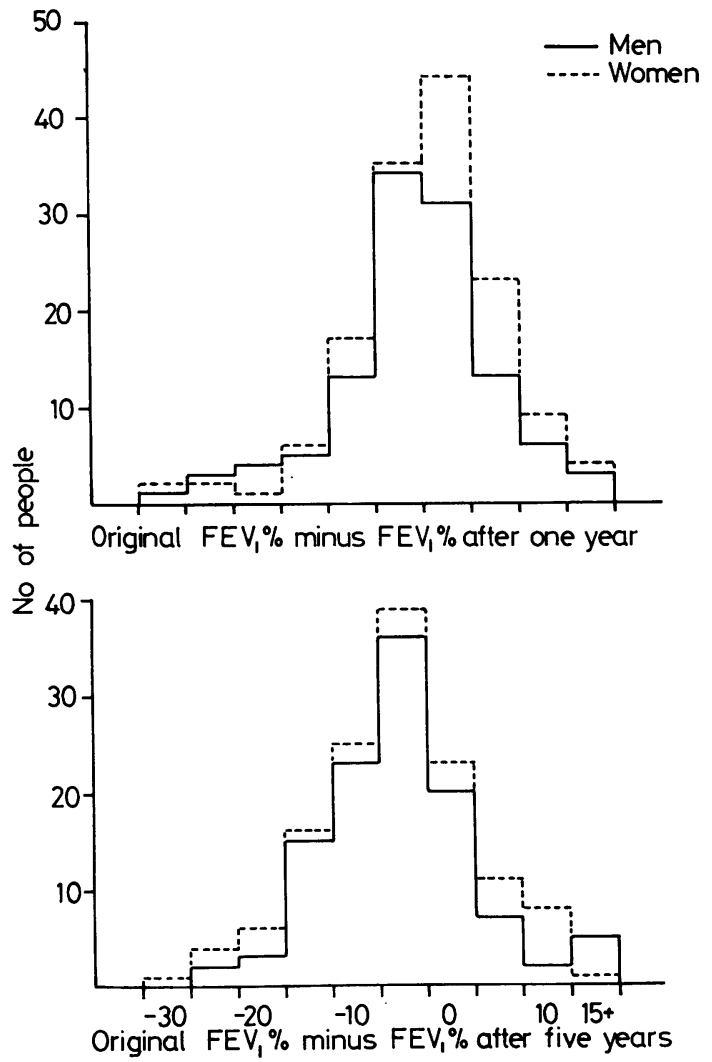

Fig 5 Distributions of one-year and five-year differences in $F E V_{1} \%$ in older men and women.

those who had not. None of these differences in either sex was statistically significant.

For each of the three variables $\left(\mathrm{FEV}_{1}, \mathrm{FVC}\right.$, $\left.\mathrm{FEV}_{1} \%\right)$ the effect of age was examined in men and in women by the linear regression of the fiveyear difference on age at entry to the study. The equations showed that the differences with time in
$\mathrm{FEV}_{1}$ and $\mathrm{FVC}$ increased significantly with increas- $\mathrm{O}$ ing age at entry, but no age effects were found in respect of differences in $\mathrm{FEV}_{1} \%$. Mean values of $\frac{\bar{c}}{\bar{\sigma}}$ one-year and five-year differences are therefore $\stackrel{\mathbb{\Omega}}{\varrho}$ displayed in table 4 in two age groups of men and women for $\mathrm{FEV}_{1}$ and FVC and in all men and all women for $\mathrm{FEV}_{1} \%$.

In both men and women mean values of differ- $\overrightarrow{\vec{\omega}}$ ences in $\mathrm{FEV}_{1}$ and $\mathrm{FVC}$ are larger in the older subjects (table 4). Seven of the ten means of one- $\vec{x}$ year differences differ significantly from zero. The $\omega$ mean values of five-year differences are all signifi- $\omega$ cantly different from zero $(\mathrm{P}<0.001)$.

COMPARISON OF PREDICTION EQUATIONS FROM THE ORIGINAL EXAMINATION AND FROM THE EXAMINATION OF FIVE-YEAR SURVIVORS Prediction equations for $\mathrm{FEV}_{1}$ and $\mathrm{FVC}$ were cal- $\frac{\stackrel{\circ}{0}}{0}$ culated, using age and height as the independent variables, in men and women without persistent cough and phlegm examined at the five-year re- $\varphi$ view. The results are compared with the pre-. diction equations from the original study in table 5. The differences between the regression coefficients are not statistically significant. The coefficient of $\bar{O}$ regression on age of $\mathrm{FEV}_{1}$ in men has become significant during the five years. The last column $\stackrel{\unrhd}{\complement}$ in the table shows values of $\mathrm{FEV}_{1}$ and FVC cal- $\overrightarrow{\vec{A}}$ culated from the regressions for a subject aged $80 \frac{3}{3}$ years with standing height of $1600 \mathrm{~mm}$. Although calculated values in five-year survivors are smaller: than such values in corresponding groups of the original study, the sizes of the standard errors of 0 estimate suggest that the prediction equations from $\underset{x}{\mathscr{Q}}$ the original study (Milne and Williamson, 1972(b)) might still be valid for clinical work.

\section{Discussion}

This longitudinal study has shown the decline, as

Table 4 Mean values with SE of one-year differences and of five-year differences in FEV , FVC, and $F E V \%$ in older men and women (volumes $m l$ BTPS)

\begin{tabular}{|c|c|c|c|c|c|c|c|c|}
\hline \multirow{2}{*}{\multicolumn{2}{|c|}{$\begin{array}{l}\text { Sex and age } \\
\text { at entry }\end{array}$}} & \multirow{3}{*}{ - $\quad$ Variable } & \multicolumn{3}{|c|}{ One-year difference } & \multicolumn{3}{|c|}{ Five-year difference } \\
\hline & & & \multirow{2}{*}{$\begin{array}{c}\text { Mean } \\
54^{*} \\
89^{*}\end{array}$} & \multirow{2}{*}{$\begin{array}{l}S E \\
27 \\
38\end{array}$} & \multirow{2}{*}{$\begin{array}{c}N \\
71 \\
42\end{array}$} & \multirow{2}{*}{$\frac{\text { Mean }}{280^{* * *}}$} & \multirow{2}{*}{$\begin{array}{l}S E \\
35 \\
55\end{array}$} & \multirow{2}{*}{$\begin{array}{c}N \\
71 \\
42\end{array}$} \\
\hline Men & $\begin{array}{l}<70 \\
>70\end{array}$ & & & & & & & \\
\hline Women & $\begin{array}{r}<70 \\
>70\end{array}$ & & $\begin{array}{l}47^{*} \\
94^{* *}\end{array}$ & $\begin{array}{l}19 \\
32\end{array}$ & $\begin{array}{l}89 \\
54\end{array}$ & $\begin{array}{l}150^{* * *} \\
229 * * *\end{array}$ & $\begin{array}{l}28 \\
42\end{array}$ & $\begin{array}{l}88 \\
52\end{array}$ \\
\hline Men & $\begin{array}{l}<70 \\
>70\end{array}$ & FVC & $\begin{array}{l}102 \mathrm{Ns} \\
156^{*}\end{array}$ & $\begin{array}{l}53 \\
60\end{array}$ & $\begin{array}{l}71 \\
42\end{array}$ & $\begin{array}{l}531 * * * \\
627^{* * *}\end{array}$ & $\begin{array}{l}49 \\
75\end{array}$ & $\begin{array}{l}71 \\
42\end{array}$ \\
\hline $\begin{array}{l}\text { Women } \\
\text { All men }\end{array}$ & $\begin{array}{l}<70 \\
>70\end{array}$ & $\mathrm{FEV}_{1} \%$ & $\begin{array}{l}58 * \\
104^{* *} \\
-0.90 \mathrm{Ns}\end{array}$ & $\begin{array}{l}25 \\
31 \\
0.80\end{array}$ & $\begin{array}{r}90 \\
54 \\
113\end{array}$ & $\begin{array}{l}251^{* * * *} \\
379 * * * \\
-2 \cdot 79 * * *\end{array}$ & $\begin{array}{l}33 \\
54 \\
0.74\end{array}$ & $\begin{array}{r}86 \\
50 \\
113\end{array}$ \\
\hline All wom & nen & & $0.50 \mathrm{Ns}$ & 0.71 & 143 & $-3 \cdot 03 * * *$ & 0.83 & 136 \\
\hline
\end{tabular}


Table 5 Prediction equations for FEV 1 and FVC, based on age and height, calculated from data from original examination and from examination of five-year survivors

\begin{tabular}{|c|c|c|c|c|c|c|c|c|c|c|c|}
\hline & \multicolumn{11}{|c|}{ Prediction equation } \\
\hline & $\begin{array}{l}\text { Sex and } \\
\text { age range }\end{array}$ & Test & Const & $\begin{array}{l}\text { Regr } \\
\text { Coeff } \\
(A g e)\end{array}$ & $S E$ & $\begin{array}{l}\text { Regr } \\
\text { Coeff } \\
(\text { Height })\end{array}$ & $S E$ & $\boldsymbol{R}$ & $N$ & $\begin{array}{l}S E \\
\text { about } \\
\text { regression }\end{array}$ & $\begin{array}{l}\text { Calculated } \\
\text { value in } \\
\text { subject } \\
\text { aged } 80 \text {, } \\
\text { height } \\
1.6 \mathrm{~m}\end{array}$ \\
\hline \multirow[t]{3}{*}{$\begin{array}{l}\text { Original } \\
\text { study } \\
(1968 / 9)\end{array}$} & $\begin{array}{l}\text { Men } \\
62-90\end{array}$ & FEV & $-3412 \cdot 5$ & $-14 \cdot 10 \mathrm{xs}$ & $8 \cdot 28$ & $3.987^{* * *}$ & 0.756 & 0.43 & 142 & 643 & 1839 \\
\hline & & FVC & $-5009 \cdot 0$ & $-18 \cdot 35^{*}$ & 8.95 & $5 \cdot 681^{* * *}$ & 0.817 & 0.53 & 142 & 696 & 2613 \\
\hline & $\begin{array}{l}\text { Women } \\
62-90\end{array}$ & $\begin{array}{l}\text { FEV } \\
\text { FVC }\end{array}$ & $\begin{array}{l}-91.97 \\
-841.1\end{array}$ & $\begin{array}{l}-26 \cdot 57^{* * *} \\
-26.97^{* * *}\end{array}$ & $\begin{array}{l}4.96 \\
5.84\end{array}$ & $\begin{array}{l}2 \cdot 307^{* * *} \\
3 \cdot 062^{* * *}\end{array}$ & $\begin{array}{l}0.441 \\
0.519\end{array}$ & $\begin{array}{l}0.50 \\
0.50\end{array}$ & $\begin{array}{l}226 \\
226\end{array}$ & $\begin{array}{l}427 \\
485\end{array}$ & $\begin{array}{l}1474 \\
1901\end{array}$ \\
\hline \multirow[t]{3}{*}{$\begin{array}{l}\text { Five-year } \\
\text { review } \\
(1973 / 4)\end{array}$} & $\begin{array}{l}\text { Men } \\
67-95\end{array}$ & FEV & $-1108 \cdot 3$ & $-30 \cdot 34^{* *}$ & $11 \cdot 15$ & $3 \cdot 322 * * *$ & 0.920 & 0.48 & 84 & 597 & 1780 \\
\hline & & FVC & $-486 \cdot 6$ & $-44 \cdot 36 * * *$ & $10 \cdot 81$ & $3.994^{* * *}$ & 0.892 & 0.60 & 84 & 579 & 2355 \\
\hline & $\begin{array}{l}\text { Women } \\
67-95\end{array}$ & $\begin{array}{l}\text { FEV } \\
\text { FVC }\end{array}$ & $\begin{array}{r}1035 \cdot 4 \\
643 \cdot 3\end{array}$ & $\begin{array}{l}-30 \cdot 33^{* * *} \\
-34 \cdot 17^{* * *}\end{array}$ & $\begin{array}{l}7 \cdot 12 \\
7 \cdot 74\end{array}$ & $\begin{array}{l}1 \cdot 760^{*} \\
2 \cdot 381^{* *}\end{array}$ & $\begin{array}{l}0.678 \\
0.737\end{array}$ & $\begin{array}{l}0.46 \\
0.50\end{array}$ & $\begin{array}{l}118 \\
118\end{array}$ & $\begin{array}{l}403 \\
438\end{array}$ & $\begin{array}{l}1425 \\
1719\end{array}$ \\
\hline
\end{tabular}

NS = not significant; ${ }^{*} P<0.05 ;{ }^{*} P<0.01 ; * * *_{P}<0.001$.

age increased, in values for respiratory function tests described by Fletcher and Peto (1977).

Prediction equations based on data from the five-year review did not differ significantly from the original equations (table 5). The exception was the coefficient of regression of $\mathrm{FEV}_{1}$ on age in men, which was significant at the five-year but not at the original examination. The prediction equations of Schmidt et al (1973) produce values greater than those recorded in the first examination in the present study, but the size of the standard errors of estimate in the present study (table 5) means the differences are less than at first sight.

A study from Sweden (Wilhelmsen et al, 1969) reported five-year differences of $330 \mathrm{ml}$ in vital capacity and $230 \mathrm{ml}$ in $\mathrm{FEV}_{1}$ in men aged 50 at entry to their study. These differences are smaller than those in older men in the present study, which has, however, shown that the differences increase with increasing age at entry. Other studies in industry (Higgins et al, 1968, Howard, 1970) have reported differences in $\mathrm{FEV}_{0.75}$ after five years. These results are not directly comparable with those from the present study but are of the same order of size. Cotes (1968) quotes a mean loss of $\mathrm{FEV}_{1}$ with age in men of $300 \mathrm{ml}$ per decade. The symmetrical distribution of differences in $\mathrm{FEV}_{1}$ over six months in the study of Fletcher and Peto (1977) caused these authors to think that sudden large irreversible falls in $\mathrm{FEV}_{1}$ were rare. The distributions of one- and five-year differences in the present study were also symmetrical.

In the present study the decline in FEV $_{1}$ and FVC increased with increasing age. This finding is in agreement with the work of Fletcher and Peto. Howard (1970) reported a similar age effect on $F E V_{1}$ and FVC changes and that FVC fell more in a given time than $\mathrm{FEV}_{1}$. He thought this was due to the greater size of FVC compared with $\mathrm{FEV}_{1}$ and noted little change in $\mathrm{FEV}_{1} \%$. The present study showed a similar greater fall with a corresponding increase in $\mathrm{FEV}_{1} \%$, which was statistically significant and of the order of $3 \%$ (table 4).

Howard thought that the variation in the rate of decline of $\mathrm{FEV}_{1}$ in individuals meant that the normal population without symptoms included subjects in whom the $\mathrm{FEV}_{1}$ was declining rapidly. Hence the "normal" regression coefficient in prevalence studies could be too high. Recent work by Fletcher and Peto has shown that $\mathrm{FEV}_{1}$ declines more rapidly as time passes in cigarette smokers than in non-smokers and that such smokers need not have symptoms. Higgins and Oldham (1962) found, in men aged 20-69 years, that the decline did not vary with age.

A ten-year follow-up of civil servants with chronic bronchitis (Oswald et al, 1967) showed that dyspnoea was the symptom that best estimated prognosis. The death rate in that study rose as the degree of dyspnoea at the original examination increased. The severer grades of dyspnoea were the symptom most likely to be associated with death in the present study.

Changes in symptom prevalence over a period are difficult to explain. Sharp et al (1973) in a seven-year longitudinal study of middle-aged men, in which the MRC questionnaire on respiratory 
symptoms was used, found that symptom prevalence recorded at the start declined during the period of study. The original proportions of those with cough and phlegm and of those who smoked cigarettes fell during the seven years. This was true of cough and phlegm in men more than in women in the present study, while the proportion who smoked declined in both sexes. Dyspnoea worse than grade 2 tended to disappear in a greater proportion of women compared with men (table 1).

With respect to incidence of symptoms in men during the period of study, Sharp et al found that $6.6 \%$ of their men developed cough and phlegm and $16.5 \%$ developed dyspnoea during seven years, the corresponding figures during five years in the present study being $7 \cdot 1 \%$ and $13 \%$.

Many subjects in the present study who appear as non-smokers at the first and at the five-year examinations (30 of 55 men and 13 of 113 women in table 1) had once smoked cigarettes but stopped before the study began. The relatively small numbers who stopped during the study (14 men, 4 women) made it difficult to assess the effect of stopping. Fletcher and Peto in their eight-year longitudinal study of working men in London were able to separate the effect of smoking in increasing the rate of decline of $\mathrm{FEV}_{1}$ with age from its effect in producing the syndrome of persistent cough and phlegm. The design of the present study and the possibly inaccurate information gathered about when smoking had ceased before the study began made it impossible to use the present study to describe such separation.

This study was supported by a grant from the Secretary of State for Scotland.

\section{References}

Berglund, E, Birath, G, Bjure, J, Grimby, K, Kjellmer, I, Sandgist, L, and Soderholm, B (1963). Spirometric studies in normal subjects. I. Forced expirograms in subjects between 7 and 70 years of age. Acta Medica Scandinavica, 173, 185-192.

Cotes, J E (1968). Lung Function. Blackwell Scientific Publications, Oxford.

Drew, C D M, and Hughes, D T D (1969). Characteristics of the Vitalograph spirometer. Thorax, 24, 703-706.

Ferris, B G, Anderson, D O, and Zickmantel, R (1965). Prediction values for screening tests of pulmonary function. American Review of Respiratory Disease, 91, 252-261.

Fletcher, C, and Petro, R (1977). The natural history of chronic airflow obstruction. British Medical Journal, 1, 1645-1648.

Higgins, I T T, Gilson, J C, Ferris, B G, Waters, M E, Campbell, H, and Higgins, M W (1968). Chronic respiratory disease in an industrial town: a nine-year follow-up study. American Journal of Public Health 58, 1667-1676.

Higgins, I T T, and Oldham, P D (1962). Ventilatoryf capacity in miners-a five-year follow-up study 8 British Journal of Industrial Medicine, 19, 65-76.

Howard, P (1970). A long-term follow-up of respiratory symptoms and ventilatory function in a group of working men. British Journal of Industrial Medicine 27, 326-333.

Kory, R C, Callahan, R, Boren, H G, and Syner, J (1961). The Veteran's Administration-Army Co operative study of pulmonary function. Americain Journal of Medicine, 30, 243-258.

Milne, J S, and Chopin, J M (1975). Reviews after ong and five years in longitudinal study of ageing pert sons. Age and Ageing, 4, 152-160.

Milne, J S, Hope, K, and Williamson, J (1970). Var? ability in replies to a questionnaire on symptoms of physical illness. Journal of Chronic Diseases, 220 805-810.

Milne, J S, Maule, M M, and Williamson, J (1971) Method of sampling in a study of older people with. a comparison of respondents and nonrespondents. British Journal of Preventive and Social Medicinę 25, 37-41.

Milne, J S, and Williamson, J (1972(a)). Respirator symptoms and smoking habits in older people wit age and sex differences. Respiration, 29, 359-370.

Milne, J S, and Williamson, J (1972(b)). Respiratore function tests in older people. Clinical Science, 42, 371-381.

Morris, J F, Temple, W P, and Koski, A (1973) Normal values for the ratio of one-second force expiratory volume to forced vital capacity. Americar Review of Respiratory Disease, 108, 1000-1003.

Medical Research Council (1965). Definition and classification of chronic bronchitis, Lancet, 1, 775 779.

Needham, C D, Rogan, M C, and McDonald, I (1954) Normal standards for lung volumes, intrapulmonar. gas mixing, and maximum breathing capacitio Thorax, 9, 313-325.

Oswald, N C, Medvei, V C, and Waller, R E (1967ळ Chronic bronchitis: a 10-year follow-up. Thorax, 22 279-285.

Schmidt, C D, Dickman, M L, Gardner, R M, an Brough, F K (1973). Spirometric standards fof healthy elderly men and women. American Review of Respiratory Disease, 108, 933-939.

Sharp, J T, Paul, O, McKean, H, and Best, W (1973). A longitudinal study of bronchitic symptoms and spirometry in a middle-aged male industriag population. American Review of Respiratory Disease 108, 1066-1077.

Wilhelmsen, L, Orha, I, and Tibblin, G (1969). Decrease in ventilatory capacity between ages of 50 and 54 in a representative sample of Swedish ment British Medical Journal, 3, 553-556.

Requests for reprints to: Dr J S Milne, East Fortun Hospital, North Berwick, East Lothian EH39 5JX. 